This item was submitted to Loughborough's Research Repository by the author.

Items in Figshare are protected by copyright, with all rights reserved, unless otherwise indicated.

\title{
Turning the other cheek to terrorism: reflections on the contemporary significance of Leo Tolstoy's 'Exegesis of the sermon on the Mount'
}

PLEASE CITE THE PUBLISHED VERSION

http://dx.doi.org/10.1017/S1755048308000035

\section{PUBLISHER}

Cambridge University Press (๑ Religion and Politics Research Section of the American Political Science Association)

\section{VERSION}

VoR (Version of Record)

\section{LICENCE}

CC BY-NC-ND 4.0

\section{REPOSITORY RECORD}

Christoyannopoulos, Alexandre J.M.E.. 2019. "Turning the Other Cheek to Terrorism: Reflections on the Contemporary Significance of Leo Tolstoy's 'exegesis of the Sermon on the Mount'”. figshare. https://hdl.handle.net/2134/6673. 
This item was submitted to Loughborough's Institutional Repository (https://dspace.lboro.ac.uk/) by the author and is made available under the following Creative Commons Licence conditions.

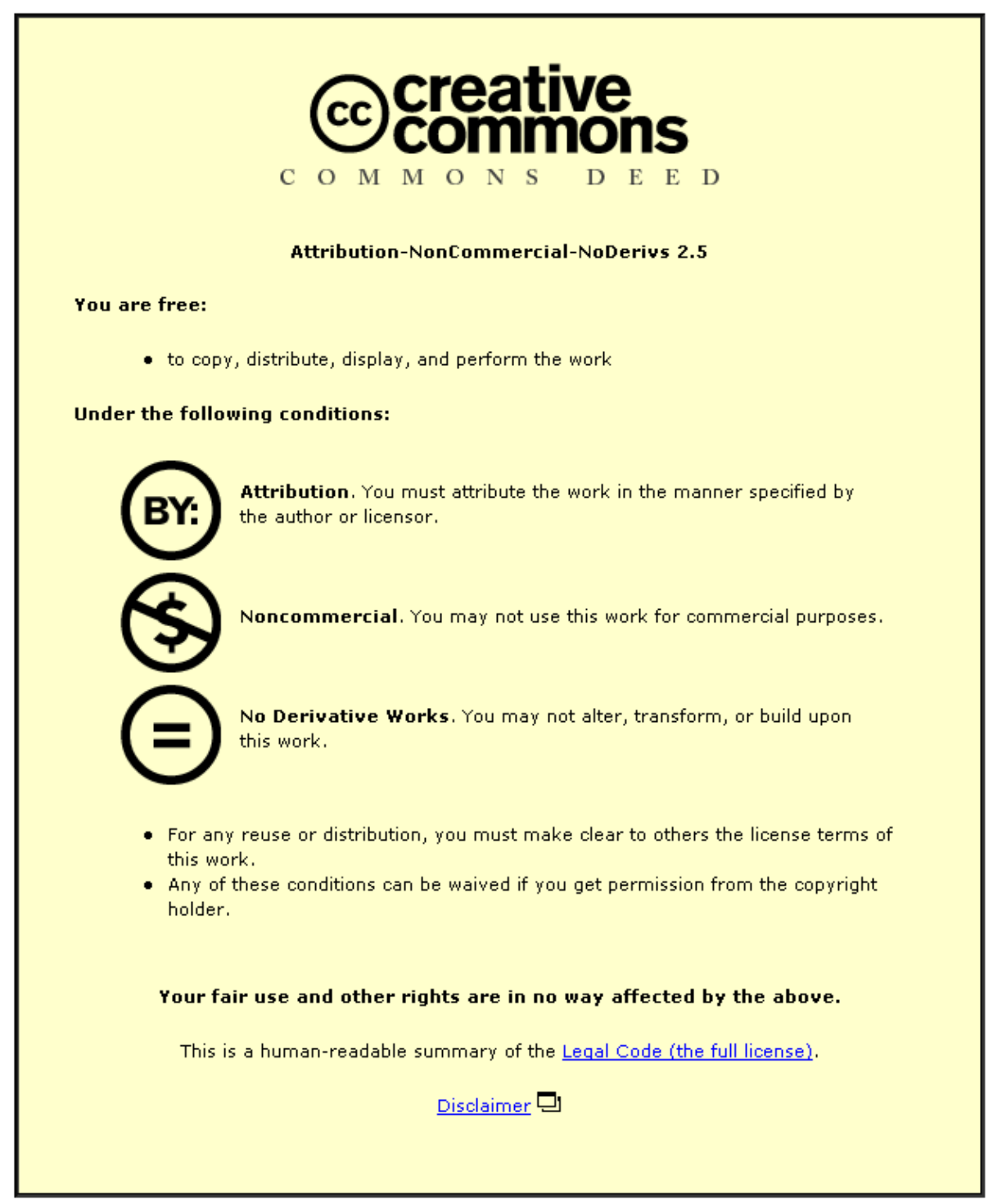

For the full text of this licence, please go to: http://creativecommons.org/licenses/by-nc-nd/2.5/ 


\title{
Turning the Other Cheek to Terrorism: Reflections on the Contemporary Significance of Leo Tolstoy's Exegesis of the Sermon on the Mount
}

\author{
Alexandre J. M. E. Christoyannopoulos \\ University of Kent
}

\begin{abstract}
The "war on terror" has brought to the fore the old debate on the role of religion in politics and international relations, a question on which Tolstoy wrote extensively during the latter part of his life. He considered Jesus to have clearly spelt out some rational moral and political rules for conduct, the most important of which was non-resistance to evil. For Tolstoy, Jesus' instructions not to resist evil, to love one's enemies and not to judge one another together imply that a sincere Christian would denounce any form of violence and warfare, and would strive to respond to (whatever gets defined as) evil with love, not force. In today's "war on terror," therefore, Tolstoy would lament both sides' readiness to use violence to reach their aims; and he would call for Christians in particular to courageously enact the rational wisdom contained in Jesus' Sermon on the Mount. Tolstoy's exegesis of Christianity may be too literal and too rationalistic, and may lead to an exceedingly utopian political vision; but it articulates a refreshingly peaceful method for religion to shape politics, one that can moreover and paradoxically be related to by non-Christians precisely because of its alleged grounding in reason.
\end{abstract}

The "war on terror(ism)," we are told by Western politicians, is a war that will take time to win; but eventually, thanks to the sheer power and determination of Western forces, freedom and democracy will prevail over "evil," over the enemies of civilization. If Leo Tolstoy could hear this,

The author wishes to thank the editors and two anonymous readers for their detailed comments on earlier drafts of this article, as well as the anonymous referees from previous journal submissions, the friends and the family members who examined earlier drafts, and the scholars who commented on presentations of this paper at the Political Studies Association and elsewhere.

Address correspondence and reprint requests to: Alexandre J. M. E. Christoyannopoulos, University of Kent, Canterbury, Kent, CT2 7NZ E-mail: ajmc2@kent.ac.uk 
however, he would be incensed, because according to him, the essence of the teaching of Jesus - a figure so central to this Western civilization - is about non-resistance to evil, about Christian love, and non-violence. Therefore, instead of rushing to overpower terrorists, Tolstoy would call for Westerners to pay more attention to Jesus' words, to honestly reflect upon the rational wisdom contained in them. He would further suggest that such a careful reading in fact reveals a political attitude that recommends an unusual and peaceful way of responding to violence. In other words, Tolstoy would argue that a truly Christian response to the "war on terror" would be radically different to the one advocated by many self-proclaimed Christians today.

This article is premised on the view that the "war on terror" calls for the political implications of religious traditions to be openly examined anew. If religious facades are not to be misused by opportunistic leaders, then scholars should not shy away from an open-minded and thorough examination of the political implications of religious traditions. This actually means approaching these religions as genuine, alternative political theories. Despite the hopes of the Enlightenment, religion today remains stubbornly embedded in politics. Therefore the direct political significance of religious philosophies continues to demand meticulous, tolerant academic attention.

Precisely on this topic, and more specifically on the political implications of Christianity, Tolstoy raised several points that could offer interesting first steps on pathways for further thinking. His approach itself may not be always careful, tolerant or academic, but his message is still pertinent and worth pondering in today's political climate, because he highlights a peaceful yet often forgotten dimension of Jesus' message to humanity. The purposes of this article, therefore, are to introduce the reader to Tolstoy's understanding of what a Christian and in fact, for Tolstoy, a rational response to violence should be; to thereby demonstrate that political acts inspired by Christianity should probably never take a violent form; to reflect, in light of this, upon some of the challenges posed by the "war on terror;" and to thereby contribute to, and invite further thinking on, what might be seen as an unconventional Christian political theory. The ultimate aim is not to provide a final answer for how Christians should respond to terrorism, but to stimulate debate by presenting Tolstoy's radical views on the topic.

To this end, a summary of Tolstoy's exegesis of Jesus' teaching will point out some of the plain moral rules that he drew out of his understanding of Christianity, in particular, the commandment never to resist evil. 
This will then provoke a few reflections on how a Christian sympathetic to Tolstoy would be expected to respond to terrorism. Given the obscurity of Tolstoy's thought today, the third part of this article will go beyond the immediate aim of reflecting on the "war on terror" by alluding to the partiality of Tolstoy's approach to religion, and to his Christian anarchist vision for society. This article will then conclude by reaffirming the relevance of Tolstoy's radical voice in the twenty-first century.

\section{TOLSTOY'S EXEGESIS OF THE GOSPEL}

Leo Tolstoy (1828-1910) is more famous today for his celebrated novels than for his critical essays on religion and politics. Yet for the last thirty years of his long life, after a traumatic period of growing existential questioning that culminated in his conversion to Christianity, Tolstoy concentrated his writings on elucidating the "true meaning" of Jesus' teaching and its consequences for the way a Christian is to approach political affairs (for comprehensive biographical information on Tolstoy, see eminent works such as Leon 1944; Maude 1930a; Troyat 1967; Wilson 1988).

His understanding of Jesus was a bluntly rationalistic one (and some of the problems with this will be discussed further below). Tolstoy deliberately disregarded the "superstitious," supernatural elements of Christianity, which he considered to have been deliberately inserted into Jesus' message by malicious political manipulators. Miracles, the Holy Trinity, the divinity of Christ, the doctrine of Original Sin, or the Redemption of mankind through Christ were all fantastic stories designed to hypnotize the masses into submission (Tolstoy 1902, 1934b, 1934f). According to Tolstoy, the existence of God can be established rationally, ${ }^{1}$ and Jesus was simply "the highest representative of [humanity's] wisdom" (Tolstoy 2001d, 507) — so the essence of Christianity was therefore not some mysterious Resurrection but the very rational teaching that Jesus personally shared with his followers. For Tolstoy, the universal authority of Jesus derives not from his divine status, but from his supreme articulation of reason.

Having thus extracted from the Gospel all these irrational additives, Tolstoy was left with a set of "moral, clear, and comprehensible rules" (Tolstoy 1902, 13), the best summary of which was to be found in Jesus' Sermon on the Mount, chapters five to seven of Matthew's Gospel. More specifically, Tolstoy regarded the second part of the fifth 
chapter as presenting "five new, clear, and definite commandments" (Tolstoy, 1902, 67) that clearly supersede the old Mosaic Law (for a more detailed explanation of this, see Tolstoy 1902, 50-66). Tolstoy summarizes these five commandments as follows: "(1) Do not be angry, but live at peace with all men. (2) Do not indulge yourself in sexual gratification. (3) Do not promise anything on oath to anyone. (4) Do not resist evil, do not judge and do not go to law. (5) Make no distinction of nationality, but love foreigners as your own people" (Tolstoy 1933, 167). These instructions were for Tolstoy to become the basis of his social, political, and economic views.

\section{Resist Not Evil}

Of all five commandments, however, one plainly stood out and revealed, according to Tolstoy, the absolute essence of Jesus' teaching — the rest of the Gospel was just further detailing of this key instruction (Tolstoy 1902, 9-25). In the King James Version of the Bible, ${ }^{2}$ this crucial directive reads as follows:

Ye have heard that it hath been said, An eye for an eye, and a tooth for a tooth:

But I say unto you, That ye resist not evil: but whosoever shall smite thee on thy right cheek, turn to him the other also.

And if any man will sue thee at the law, and take away thy coat, let him have thy cloak also.

And whosoever shall compel thee to go a mile, go with him twain.

Give to him that asketh thee, and from him that would borrow of thee turn not thou away. (Matthew 5:38-42, King James Version's italics removed)

Tolstoy understood Jesus as spelling out a completely new and wiser method for human beings to deal with evil: when coerced, do not retaliate, but obey, and do so exemplarily — even if you get persecuted for it.

Tolstoy further reflected on this startling, lucid command, and realized that truly, the whole history of mankind displayed repeated and yet ultimately disastrous endeavors to resist evil with evil, to respond with violence to threats of violence, to go to war to prevent another war (Kennan 1887). But violent resistance only aggravates any given problem: for Tolstoy, it aggrieves the relatives of those who have been wronged, and worse, it can then be used to legitimize the other side's use of violence in reply; the 
parties are then caught in a brutal game of tit-for-tat that spreads into "a universal reign of violence" (Kennan 1887, 259). Thus, when the oppressed grow stronger and eventually take control, they resentfully avenge themselves, and in turn become the new oppressors (Tolstoy 1987b, 161-164). In the end, an eye for eye can only make the whole world go blind. ${ }^{3}$

It became clear to Tolstoy that this old approach to evil is both irrational and unchristian. It is irrational because in the long run, it does not guarantee that the end for which violent means are used will be satisfactorily secured. And it is unchristian because Jesus blatantly condemned it - both verbally and in the way he responded to his arrest, trial, and crucifixion. In Tolstoy's words, this was Jesus' message to mankind: "You think that your laws correct evil; they only increase it. There is only one way of extirpating evil - to return good to all men without distinction. You have tried your principle for thousands of years; try now mine, which is the reverse" (Tolstoy 1902, 41). Tolstoy then proudly consolidated his point:

It may be affirmed that the constant fulfilment of this rule is difficult, and that not every man will find his happiness in obeying it. It may be said that it is foolish; that, as unbelievers pretend, Jesus was a visionary, an idealist, whose impracticable rules were only followed because of the stupidity of his disciples. But it is impossible not to admit that Jesus did say very clearly and definitely that which he intended to say: namely, that men should not resist evil; and that therefore he who accepts his teaching cannot resist. (Tolstoy 1902, 18-19)

An honest Christian, according to Tolstoy, cannot deny that Jesus called for men not to resist evil. So for Tolstoy, whoever describes himself as a Christian and yet is caught resisting evil would have to be, quite frankly, a hypocrite - namely one of those whom Jesus denigrated as blind fools who appear righteous but are in fact full of iniquity (Tolstoy 1902, 50-66; Matthew 23; Luke 11).

The implications of this commandment for how Christians are to conduct international relations are obvious: if resistance to evil is rebuked by Jesus, then war is a plainly unchristian act. That so many wars have been fought in the name of Christianity does not prove war to be compatible with it; what it does show, however, is that Jesus' teaching has been (for Tolstoy, intentionally) evaded for so many centuries (Tolstoy 1902, 1934b, 1934h, 2001c). ${ }^{4}$ Besides, apart from the whole Gospel in general, which he felt confirmed the commandment of 
non-resistance, Tolstoy further pointed to two other specific passages within the Sermon on the Mount that corroborate, from a different angle, the Christian rejection of war.

\section{Judge Not}

The first such passage is one that Tolstoy incorporates in his broader exegesis of the commandment not to resist evil, since it is alluded to in the same breath when Jesus refers to "being sued at the law." Later in the Sermon, in the beginning of Matthew's seventh chapter, Jesus further states the following:

Judge not, that ye be not judged.

For with what judgement ye judge, ye shall be judged: and with what measure ye mete, it shall be measured unto you again.

And why beholdest thou the mote that is in thy brother's eye, but considerest not the beam that is in thine own eye?

Or how wilt thou say to thy brother, Let me pull out the mote out of thine eye; and, behold, a beam is in thine own eye?

Thou hypocrite, first cast out the beam out of thine own eye; and then shalt thou see clearly to cast out the mote out of thy brother's eye. (Matthew 7:1-5, King James Version's italics removed)

Tolstoy additionally remarks that the order not to judge one another is further reiterated by several of Jesus' parables, by his response to the proposed stoning of the adulteress, as well as much later in the New Testament by James and by Paul (Luke 6:37-42; John 8:1-11; James 4:11-12; Romans 2:1-4).

And again, the instruction, says Tolstoy, could not have been much clearer. Human beings are fallible and hence unqualified to judge one another, let alone punish any perceived wickedness. Tolstoy interprets "judgement" In the broad sense of not just forming an opinion about the situation (beholding the mote), but acting upon it (pulling it out), especially without considering whether one is not guilty of a similar fault (the beam). Since all men are at least partly blinded by their own wickedness, for them to dare to accuse, judge, and punish one another is misguided and somewhat hypocritical. Man has no prerogative to convict his fellow. Therefore this instruction does indeed bring further credence 
(albeit indirectly) to the above rule of non-resistance: if one is unable to correctly discern what is evil from what is not, not least because one is oneself tainted by evil, then acting upon such perception is bound to produce further harm. One cannot resist and exterminate evil if one is unable to accurately assess one's own evil in the first place (Tolstoy 1902, 26-40).

\section{Love Your Enemies}

The other passage that leads Tolstoy to conclude that war must be unchristian is actually the commandment that immediately follows the one of non-resistance to evil, wherein Jesus calls his followers to love even their enemies:

Ye have heard that it hath been said, Thou shalt love thy neighbour, and hate thine enemy.

But I say unto you, Love your enemies, bless them that curse you, do good to them that hate you, and pray for them which despitefully use you, and persecute you;

That ye may be the children of your Father which is in heaven: for he maketh his sun to rise on the evil and on the good, and sendeth rain on the just and on the unjust. (Matthew 5:43-45)

Here, however, Tolstoy initially felt this instruction to be an "exaggeration" of the command not to resist evil (Tolstoy 1902, 88). How could one actually love one's personal enemy? Not resisting evil would be very hard but could be done, yet bringing oneself to genuinely love one's enemy sounded strictly impossible. And then Tolstoy realized there was another oddity: while in the previous four commandments, Jesus quotes the exact words of the old law, here, he appears to be misquoting it (Tolstoy 1902, 89). Why would Jesus calumniate the old law?

Tolstoy found the appeasing answer to both questions in a lexicon. That is, as many other passages from the Bible indeed confirmed, "neighbour" In Jewish simply meant a fellow Jew. Similarly, "enemy," in the Gospel is usually used not to denote a private enemy, but a public or national one. This would then make sense of the commandment: first, Jesus does not calumniate the old law, but he simply brings together the many ancient orders to oppress other nations into one single saying; second, again according to Tolstoy, Jesus is not asking his followers to love their personal enemies, but simply to consider foreigners 
with the same love and respect as fellow countrymen. In other words, the old law stimulated patriotism, but Jesus supersedes it with a new command; that is, Jesus calls his disciples to disregard national boundaries and to treat all nationalities in the same loving way. Patriotism is thus rejected, but so are all actions that are based upon, or that further incite, national distinctions - such as war or military preparations for war (Tolstoy 1902, 90-92). So from yet another angle, international warfare is, for Tolstoy, a most unchristian activity. ${ }^{5}$

\section{The Heart of Jesus' Message}

Tolstoy's idiosyncratic exegesis of the Bible therefore ignored established commentaries and understood Jesus' teaching in a very literal and rational manner. He stripped away all elements of supernatural mystery and was thus left only with an ethical system, a set of moral rules for conduct that he considered to be best expressed in the Sermon on the Mount. ${ }^{6}$ Even if one-sided and disrespectful to the rest of the traditional canon, Tolstoy does emphasize a thought-provoking dimension of the Christian teaching, one that is in the heart of the New Testament for all to see. Whatever the shortfalls of his hermeneutical method (which will be returned to further below), he does draw out Jesus' very eloquent condemnation of any form of resistance to evil.

The implications for the realm of politics and international relations are fairly self-explanatory: war or terrorism, the most extensive forms of resistance to (whatever gets defined as) evil, are for Tolstoy, clearly unchristian activities. So while justifications for resistance may be fabricated on a variety of theoretical foundations, they cannot coherently be rooted in a Christian perspective of the world. And anyhow, resistance is in fact an irrational method in the face of evil, because violence breeds further violence.

The beauty of the Christian message is thus that there can be no difference between means and ends. The means are the ends, and by the same token violence is evil. Hence, to use a more Christian phrase, only love can bring about love. War cannot bring lasting peace; resistance can only bring more resistance further down the line. If one wants peace, one must act peacefully. Terrorizing one's neighbor guarantees terrorism in return; loving one's neighbor is the only way to realistically expect love in return. That, for Tolstoy, is the absolute essence of the Christian teaching. 


\section{Protecting Our Loved Ones}

Many objections to pure non-resistance have been formulated over the years, and Tolstoy responds to some of them in his writings (for instance, Tolstoy 1902, 19-25, 85-95; Tolstoy 2001c, 34-54). Due to limited space, they cannot all be listed here. In any case, Tolstoy's typical answer is that none of the usual objections are actually grounded in Jesus' teaching. They are based on all sorts of theoretical arguments, but not on what Jesus said.

One such objection, however, ought to be addressed here, because it seems to be grounded in scripture, and because limited violence and war continue to be based upon it. The argument is that one's love for one's neighbor implies a duty to protect him, even by the reluctant adoption of violence if necessary. The more extreme version of this argument asks how a Christian non-resistant would react if his own child was being attacked.

Tolstoy responds to this objection several times across his writings (Kennan 1887, 256-259; Tolstoy 1967b, 186-188; Tolstoy 1975, 21-23; Tolstoy 1987b, 214-216; Tolstoy 2001b, 534). For a start, he remarks that it is generally but mistakenly assumed that the only possible reply to save the child is to kill the assailant (Tolstoy 1967b, 186). Yet he notes that it is never certain that an evil act would have indeed been committed - but that our own violence would itself be evil and a likely cause of further evil (Tolstoy 1967b, 186-188; Tolstoy 1987b, 214-216; Tolstoy 2001c, 39-40). For Tolstoy, the only type of response available to a Christian faithful to Jesus' teaching would be to "plead with the assailant" or to "interpose his body between the assailant and the victim," but that "he cannot deliberately abandon the law he has received from God" (Tolstoy 1967b, 187). Either way, violence is not the only option.

Moreover, Tolstoy writes, "None of us has ever yet met the imaginary criminal with the imaginary child, but all the horrors which fill the annals of history and of our own times came, and come, from this one thing, namely, that people will believe they really foresee speculative future results of action" (Tolstoy 1967b, 188). Men are convinced violence will lead to the desired solution and thus fill the annals of history with their violent actions, which that one imaginary child continues to legitimize. As Tolstoy replied to someone else who brought up this argument,

I have never, except in discussions, encountered that fantastic brigand who before my eyes desired to kill or violate a child, but [...] I perpetually did 
and do see not one but millions of brigands using violence towards children and women and men and old people and all the labourers, in the name of a recognized right to do violence to their fellows. (Tolstoy 2001b, 534)

People, Tolstoy laments, worry about an imaginary — or at least very rare - defenseless child, but not about the real suffering of so many of their neighbors as a result of the acceptance of violence as an appropriate method to respond to real or hypothetical aggression (Tolstoy 1975, 21-22).

Tolstoy does not brush aside the very real torture, rape and murder which are committed in warfare. He is acutely aware of these horrors of war. Indeed, his celebrated War and Peace reveals his fascination with the social processes that can lead sensible human beings to such mass slaughter as the Napoleonic Wars (Tolstoy 1993b). After his conversion to Christianity, however, the slight touches of awe which may have transpired in his earlier writings disappear, and Tolstoy adopts an outright aversion of war in all its forms. As an illustration, these are the words he writes to describe the next war which he believes Russia to be inevitably heading toward:

And hundreds of thousands of simple kindly folk, torn from their wives, mothers, and children, and with murderous weapons in their hands, will trudge wherever they may be driven, stifling the despair in their souls by songs, debauchery, and vodka. They will march, freeze, suffer from hunger, and fall ill. Some will die of disease, and some will at last come to the place where men will kill them by the thousand. And they, too, without themselves knowing why, will murder thousands of others whom they had never before seen, and who had neither done nor could do them any wrong. (Tolstoy 2001a, 449)

Tolstoy is aware of the horrors of war, but where he differs from the majority of political thinkers, and indeed where the essence of his contribution lies, is in his utter conviction that to eradicate such horrors, human beings need to stop fighting and start loving and forgiving, even at the cost of very real sacrifices and suffering in the short run. That is what he understands Jesus' teaching to be about.

For Tolstoy, the suffering resulting from non-resistance is not worse than the suffering resulting from war - but at least it might lead humanity toward a brighter future. Of course, it is very difficult, especially when talking about one's own child. But for Tolstoy, the use of violence in 
defense will only aggrieve yet another family - and the cycle of violence thus continues. In a sense, Tolstoy is a cold rationalist: it is just rational for him not to resist because, first, resistance does not guarantee that one will save one's life or that of one's child anyway, and second, non-resistance is the only way to open the possibility for peace in the long run. According to Tolstoy's understanding of Jesus, non-resistance is the only truly rational option in the long run, and in the short run, the suffering it entails is not worse than the suffering likely to ensue from violent resistance. Therefore, even to protect one's loved ones, Tolstoy does not believe violence can be justified.

Perhaps the most eloquent and powerful response to this objection, however, comes not from Tolstoy, but from Adin Ballou, a non-resistant whom Tolstoy quotes at length and with respect (Tolstoy 2001c, 11-21). Ballou's answer is quite long, but every sentence of it is powerful enough to warrant the following extended quotation:

'Well,' says the objector, 'I should like to know how you would manage matters if the ruffian should actually break into your house with settled intent to rob and murder. Would you shrink back like a coward and see your wife and children slaughtered before your eyes?' I cannot tell how I might act in such a dreadful emergency - how weak and frail I should prove. But I can tell how I ought to act - how I should wish to act. If I am a firm, consistent non-resistant, I should prove myself no coward; for it requires the noblest courage and the highest fortitude to be a true non-resistant. If I am what I ought to be, I should be calm and unruffled by the alarm at my door. I should meet my wretched fellowman with a spirit, an air, a salutation, and a deportment so Christ-like, so little expected, so confounding, and so morally irresistible that in all probability his weapons of violence and death would fall harmless to his side. I would say, 'Friend, why do you come here? Surely not to injure those who wish you nothing but good? This house is one of peace and friendship to all mankind. If you are cold, warm yourself at our fire; if hungry, refresh yourself at our table; if you are weary, sleep in our bed; if you are destitute, poor, and needy, freely take of our goods. Come, let us be friends, that God may keep us all from evil and bless us with his protection.' What would be the effect of such treatment as this? Would it not completely overcome the feelings of the invader, so as either to make him retreat inoffensively out of the house, or at least forbear all meditated violence? Would it not be incomparably safer than to rush to the shattered door, half distracted with alarm, grasping some deadly weapon and bearing it aloft, looking fiery wrath and mad defiance at the enemy? How soon would follow the mortal encounter, and how extremely 
uncertain the outcome? The moment I appeared in such an attitude (just the thing expected), would not the ruffian's coolness and well-trained muscular force be almost sure to seal the fate of my family and myself? But in acting the non-resistant part, should I not be likely, in nine cases out of ten, to escape with perfect safety? (Ballou 1839, 15-16)

Ballou's answer is so moving in part because it recalls so eloquently that non-resistance is not separable from a broader Christian attitude of love and care: feeding the poor, sheltering the homeless, caring for the afflicted - true love of neighbor and enemy - is likely to prevent anger and violence from arising in the first place. He admits that it is difficult, and that he might fail in doing what Jesus demands, but he rejects the idea that one ought to use violence to protect one's loved ones, because in the long run, a loving and non-resistant attitude is more likely to save us than an aggressive response.

Tolstoy agrees: any violent response sows the seeds of further violence, and justifies the other side's right to use violence to protect what it regards as its own vital interests (Kennan 1887). Moreover, in a truly Christian society - where no-one would use violence against others, where all would care for, give to and help every single human being - in such a society, the risk for violence to arise would be very low in the first place (Tolstoy 1902, 218). Thus the best response to the imaginary criminal wishing to rape or murder the imaginary child is not necessarily to use violence in reply, and anyway, a truly Christian society would almost eliminate the risk of such violence arising in the first place. Tolstoy (and Ballou) therefore rejects the argument whereby violence may be needed to protect one's neighbor. For him, there can be no compromise, no exception to Jesus' rule of turning the other cheek. Besides, he notes that "no confirmation of such an interpretation can be found anywhere in Christ's teaching" (Tolstoy 2001c, 38).

\section{IMPLICATIONS FOR ANY CHRISTIAN RESPONSE TO TERRORISM}

Such an understanding of Christianity has at least two important implications for the "war on terror:" for a start, Christians would be called to renounce the use of violence; but also and more fundamentally, the problem of terrorism would be seen in a very different light in the first place. 


\section{Renouncing the Use of Force}

The first and most imperative comment that Tolstoy would make on the "war on terror" would be to point out the dangerous delusion that both sides entertain by thinking that their end justifies whatever violent means. For Tolstoy, this delusion is the very evil that must be overcome, because Jesus rationally establishes that whether the other is truly wicked or not, the only constructive reaction is non-resistance - it is the only long term solution (Tolstoy 1902, 1934d, 2001c).

This does not mean that one ought not to react at all, to remain hopelessly passive when attacked. Jesus describes what action to take when he calls for turning the other cheek, for instance, whatever the consequences - not "for sheer suffering's sake," but so as not to resist evil, even if that does entail suffering (Tolstoy 1902, 17). It is a purposeful response, one that represents an ultimate act of love, patience, and forgiveness. The hope is that such compelling demonstration of love is bound to eventually soften the heart of the violent enemy, of "evil." Of course, there is no guarantee that it will. It opens the road of apparent victory to the enemy, but the victim's suffering can in turn touch the heart of the enemy - at least of substantial sections of its population. Thus, while the enemy may be seemingly winning all the battles in the short run, in the broader campaign for hearts and minds, his physical force could well result in moral failure, and an eventual change of heart. Willingness to suffer out of love and forgiveness can have a powerful moral effect on the aggressor.

After all, Jesus' sacrifice did ultimately enchant many disbelievers; and Gandhi, who was influenced by Tolstoy and considered him "one of the clearest thinkers in the western world" (Tolstoy 1937b, 1937d, 414), did succeed in overpowering the mighty British Empire. Gandhi in turn inspired Martin Luther King and the "peaceniks" of the 1960s, both of which also achieved some success in the causes they were campaigning for. Put simply, love, as a tactic, can work; the battle can be won on moral grounds. Non-resistance does not imply the final victory of the enemy; on the contrary, it can ultimately win him over, and do so in a non-coercive and reputable way.

But here an ambiguity arises: Tolstoy, and even more so, some of his twentieth century followers, would seem to have somewhat innocently misread the "non-resistance to evil" of Matthew's chapter 5, verse 39, as "non-resistance to evil by evil." That is, it would seem that Tolstoy genuinely misinterpreted the injunction to mean that no physical force 
should be used to resist evil - hence that non-violent resistance could be tolerated (Maude 1930b, 250; Maude 1933, xv). Indeed, to George Kennan's question whether resistance to oppression was justifiable, Tolstoy replied: "That depends upon what you mean by resistance; if you mean persuasion, argument, protest, I answer yes; if you mean violence - no. I do not believe that violent resistance to evil is ever justifiable under any circumstances" (Kennan 1887, 256). ${ }^{7}$

Did Tolstoy thereby misapprehend Jesus' commandment? Did Jesus, in fact, never ever resist? In all fairness, Tolstoy probably estimated that Jesus did sometimes "resist" to the extent that he spoke out, argued with his detractors, and tried to persuade them of their wrong. Does this mean that Jesus did not abide by his own instruction? The answer depends in part on how much one focuses on the letter rather than the spirit of the Sermon. Jesus' actions were always grounded in the spirit of love. In the end, the highest principle and ultimate reference on which all Christian guidelines are based is love - Jesus frequently repeats that love of God and of one's neighbor are the two most fundamental commandments on which the whole law subsequently hangs (for example, Matthew 22:36-40; Mark 12:30-31; John 13:34-35). So for instance, in cases where strict non-resistance would imply the transgression of the more fundamental Christian principle of love, then the secondary command of non-resistance would presumably have to be proportionally moderated.

Tolstoy for example, called for men to protest against their conscription into the army ${ }^{8}$ and for citizens not to pay taxes, both in order to deny the state its chief instruments of violent oppression (the next section will further explain why Tolstoy considered the state to be evil). Yet he also said that nevertheless, "following the command of non-resistance to evil, men should yield what goods and labor the authorities may demand" (Tolstoy 1933, 288). Thus, one should not automatically obey - in anticipation, as it were, of a future threat of violence - but only when eventually pressed should one then yield (or not resist). For instance, one should neither willingly pay taxes nor resist the state's eventual compulsory seizure of them. And even when yielding to force, Christian love should always remain paramount. So for example, if forced into a military campaign, then one should still not kill fellow human beings - that is, not fire back when shot at. No violence should be used, and whatever alternative to it is adopted, love of God and of one's neighbor should always remain the supreme benchmark for all action. 
In short, there is apparently no easy, nicely predefined answer to any given situation where one may be driven to feel like resisting. For sure, violent resistance would still clearly be at odds with Jesus' command. Whether non-violent resistance could sometimes be tolerated, however, remains unclear. When faced with evil, some response is certainly called for; but it seems that this reaction, coming from an honest Christian, could never be violent. Tolstoy's own reaction to violence was to spread his gospel in various essays, plays, and novels - his protests were largely verbal. ${ }^{9}$ Gandhi applied the principle of non-violence much more confrontationally; King and later pacifists pushed it even further into tactical political activism.

Either way, according to Tolstoy, violence and violent resistance stand plainly condemned by Jesus' teaching. If one must resist because, say, not doing so would force a worse transgression of the spirit of Jesus' teaching, then one should at least not use violence in such resistance. Even better and certainly more Christian, however, would be non-resistance and forgiveness - the symbolic turning of the other cheek. In the "war on terror," therefore, Tolstoy would be eager to remind "Christians" that any use of violence would stand condemned by Jesus and that the spectrum of possible Christian responses to terrorism would range quite narrowly from non-resistance to non-violent resistance - anything more would reveal a disobedience of Jesus' commandments.

At any rate, whether the "correct" interpretation is closer to strict nonresistance or to a more ambiguous non-violent resistance, following either method remains an extremely difficult task. Then again Jesus warned, as Tolstoy reminds us, that he who has not taken up his cross - that is, he who is not prepared to face the ultimate consequence of non-resistance to evil - cannot be his disciple (Tolstoy 1902, 18; Matthew 16:24-28; Mark 8:34-38; Luke 9:23-27). ${ }^{10}$ The path shown by Jesus is a difficult one that can only be trod by true martyrs. A "martyr," etymologically, is he who makes himself a witness to his faith. And it is the ultimate testimony to one's faith to be ready to put it to practice even when one's very life is threatened. But the life to be sacrificed, it should be noted, is not the enemy's life, but the martyr's own life - killing others is not a testimony of love, but of anger, fear, or hatred. For Tolstoy, therefore, a true martyr to Jesus' message would neither punish nor resist (or at least not use violence to resist), but would strive to act from love, however hard, whatever the likelihood of being crucified. ${ }^{11} \mathrm{He}$ would patiently learn to forgive and turn the other cheek, even at the risk of death. Such would be the only way to 
eventually win the hearts and minds of the other camp and open up the possibilities for reconciliation in the "war on terror."

\section{On Terrorism}

For that matter, the expression "war on terror" is unhelpful, really. For one thing, from the victim's perspective, any act of violence can be terrifying. That is, to the extent that any use of force "terrorizes" the targeted population, war is terrorism, only with more conventional tactics. True, terrorists strike in a deliberately indiscriminate manner, whereas conventional armies at least try to be more precise in their selection of targets. But collateral damage, the heavily disproportionate scale of conventional power, and the typical perception that one is suffering unjustly from the consequences of warfare, together ensure that from the perspective of the one whose cheek is struck, war can easily be perceived as an act of violence that is just as terrifying as terrorism (for an interesting and controversial discussion of what constitutes terrorism, and on how a state's actions can also be seen to amount to terrorism, see Chomsky 2002).

Besides, Tolstoy would refuse to label terrorists as inhuman or evil beings per se; for him, these are human beings whose mistake was to choose the evil method of violence as a desperate response to perceived injustices against their people and values. It is not the terrorists who are "evil," but their reaction to what they themselves considered to be "evil" in the first place. ${ }^{12}$ So although there are important differences between conventional warfare and terrorism, for Tolstoy, both tactics spring from the same mistaken attitude to what is perceived as evil — and in fact, it is in this very mistake that the evil resides. This is why "war on terror" is an unhelpful expression; if anything, it accidentally betrays a wide spread blindness to the self-fulfilling origin of the very problem that this "war" claims to tackle. More often than not, terrorists justify their actions as the last available option to respond to acts of violence committed against them; so responding to terrorism by further violence, for Tolstoy, can only guarantee a worsening cycle of violence for the future.

According to Tolstoy, therefore, the problem is not terrorism but the use of force, of which terrorism is just another (admittedly particularly gruesome) method. Tolstoy would therefore predict that terrorism will not be resolved by war; it will spread. In his own era, Tolstoy condemned both the state's violence and the revolutionaries that tried to violently 
overthrow it (using methods akin to terrorism), because both used violent means to achieve their aims, and so by their acts, both were only aggravating the situation (Tolstoy 1937c, 1937e, 1937f). The real problem, according to Tolstoy, is anyone's readiness to use violence in attempting to resist the other. Evil will not be defeated by violence, because what is evil in a wicked act is not the actor as such, but the very violence that this actor is ready to inflict.

In other words, the harmful element in "us versus them" is not "them," but "us" inasmuch as we see the situation as a fierce "versus." To the extent that both sides of the "war on terror" are ready to use violence either in alleged self-defense or in open "crusade" against one another, by that very act they embody the "evil" they claim to be trying to eliminate. And until both sides grasp this, Tolstoy would expect the "war on terror" to painfully linger on. Therefore, Tolstoy would call for both antagonists in the "war on terror" not to use violence in their attempt to achieve their vision for society. Surely, he contends, human beings must be able to devise "better means of improving the conditions of humanity than by killing people whose destruction can be of no more use than the decapitation of that mythical monster on whose neck a new head appeared as soon as one was cut off?" (Tolstoy 1937e, 197)

Back in his own time, Tolstoy had tried to warn about the terrible cycle of violence that was likely to engulf both his country, and the world at large if Jesus' advice was not heeded (Tolstoy 1937c, 1937e, 1937f, 2001a, 2001d). And for a time, his fellow Russians did seem to be carefully listening to his voice; Tolstoy certainly became a very influential figure in Russia - a commentator indeed reports that there were, at the turn of the century, two powers in Russia: Tsar Nicholas II and Leo Tolstoy (Kentish 1987, 9). But in the end, Tolstoy's message was not to be heard amid the voices calling for violent revolution and war, and shortly after his death in 1910, the world entered perhaps the darkest ages of its history so far. Various heads of the mythical monster were cut-off, both nationally (the Bolshevik Revolution) and internationally (the First World War), only for new ones to promptly replace them.

Now that the world is becoming engulfed into yet another war of global proportions, Tolstoy would once again call for the moderates from both sides to seriously ask themselves whether the path they are choosing can really lead them to the place they are aiming to arrive at. He would campaign for forgiveness and understanding rather than condemnation and retaliation. He would probably invite the West to reconsider the foreign policy which has driven human beings to commit suicide 
in order to harm other human beings. He would probably argue that a neighbor's resort to terrorism is the symptom of a failure on our part to love our neighbor in the first place, in other words, that our enemy's violence is not separable from our own. He would probably ask Westerners to consider the evil which they are the cause of before they lecture their brothers on their actions. He would probably appeal for the time and effort committed to resistance to evil - the enormous "defense" budgets of "Christian" nations - to be spent on loving and caring for all human beings instead. ${ }^{13} \mathrm{He}$ would probably claim that if Westerners want to be treated with love and not hatred, they need to cultivate that love in the first place — "love your enemies," he says, "and you will have none" (Tolstoy 1937a, 250). ${ }^{14}$

Tolstoy did not witness the international terrorism of today. He wrote in his context which, domestically, was one of revolutionary violence and equally brutal counter-revolutionary repression, and internationally, of military escalation, nationalist passions, and alliances for war. His central main message was to call for all sides to forego any use of violence and, in that sense, to try to "turn the other cheek" instead of striking "an eye for an eye" and "a tooth for a tooth" (Tolstoy 1937c, 1937e, 1990a, 1990b). He thought this was the only rational response in the long run. Hence, on the same grounds of universal reason as best articulated by Jesus, he would advocate the same today - but he would expect the followers of Jesus to lead the way. Moreover, in our context, as then, he would probably argue that the state should be abolished given that, as will be explained below, for him, the state cannot but be a fundamental cause of violence. More to the point, he would encourage Christians to live a very different and simpler life of care and sacrifice for one another, not least since this would prevent violence and hatred from arising in the first place (Tolstoy 1898, 1934c, 1990b). Above all, he would enjoin Christians to enact the moral rules clearly spelt out by Jesus. Even in the face of indiscriminate terrorism, the challenge for the follower of Jesus is to refrain from reacting with force. For Tolstoy, Jesus and in fact reason itself both suggest that violent resistance cannot and will not work in the long run.

\section{THE EXTREMES OF TOLSTOY'S THINKING}

Tolstoy's likely commentary on today's "war on terror" — the main subject of this article - has now been considered. However, since his 
religious and political writings are fairly unknown today, this next section extends beyond the immediate purpose of this article to point to further radical idiosyncrasies of Tolstoy's religious and political thinking, and their indirect relevance to his likely reflections on the "war on terror," first by highlighting some of the problems with Tolstoy's rationalistic approach to religion, and then by drawing a brief sketch of the Christian anarchism which his systematic Christian pacifist logic led him to advocate.

\section{Reason, Religion, and Morality}

According Tolstoy, the radical prescription of non-resistance could be reached by both religion and reason, because for him, reason naturally leads into religion (Tolstoy 1934e, 1934h). Tolstoy had decided that the existence of God could be rationally established, and in fact, it was this conclusion that eventually got him over his serious existential crisis in the first place (Tolstoy 1934h, 1987a). He further believed that all rational, thinking human beings would be bound to eventually find themselves in the same existential torment as him, until they reached the same rational conclusion that proved that God must necessarily exist. Moreover, since God truly exists, it followed that proper morality has to be based on God, that only religion can provide a sound morality on which to base one's life (Tolstoy 1902, 1934d, 1934e, 1934h).

Besides, Tolstoy claimed that all religions and all the wise teachers of mankind have all come to this very same conclusion. Tolstoy studied many religious and philosophical traditions, and reckoned that they all amount to the same moral teaching — they all teach the same, delightful Law of Love. After all, if a proper relationship to God has to be founded upon reason, it is quite logical to conclude that all sensible religious traditions must propose the same moral guidelines for human conduct. And for Tolstoy, the most articulate expression of such divine morality is to be found, quite predictably, in Jesus' Sermon on the Mount. Tolstoy reached the contentious conclusion whereby Christianity, properly understood, presents the most complete summary of all religions and with it the best illustration of the ideal relationship between religion and politics (Tolstoy 1902, 1934h).

Is Tolstoy justified in extending Jesus' commandments into other metaphysical and religious traditions? For instance, would a Muslim 
scholar truly identify with the essence of Tolstoy's interpretation of Jesus? Can Tolstoy's understanding of Jesus really help transcend the differences between and among major world religions? Or could it, at least, bring moderates on the two sides of the "war on terror" to open a peaceful dialogue in which new ways to tackle the problem of terrorism could be explored? Besides, can a religious perception of the world really be reached by pushing reason to its limits? Tolstoy's answers may be radical and perhaps overoptimistic, but they are worth reflecting upon in today's political climate. He may be one-sided in his interpretation of Christianity, but if he is right, at least in his radical assessment of the cycle of violence and the only way out of it, then our current course of action is less of a solution than a promise of further violence in the future.

That being said, Tolstoy's rationalization of religion is clearly not without problems. For a start, his "proof" of the existence of God is in fact far less straightforward and convincing than he thought it to be. A proper critical analysis of this "proof" falls out of the scope of this paper, but the point here is that his particular blending of reason and religion is not likely to convince most of his readers. Indeed, some have accused Tolstoy of detaching Christianity from its essentials (for some criticism on Tolstoy's view of religion, see Greenwood 1975; Maude 1930a; Spence 1967; Stepun 1960).

In truth, Tolstoy's exegesis of the New Testament was probably too fanatical, too rigid in its literalism, too narrow-minded in its rationalism - and in that sense, he is just another example of religious (albeit nonviolent) extremism. To be sure, even though this would contradict his own exegesis of Jesus' message, Tolstoy was in fact quite judgmental after all (something he seems to admit openly only in Tolstoy 1937c). He was quick to accuse many self-defined Christians of actually being unchristian hypocrites. True, he did not punish or use any force against those he condemned, but he did castigate many of his brothers that he thought had "a mote in their eye." He was fanatical about what he understood to be the transparent truth of Jesus' teaching. That is to say, in his severely judgmental interpretation of Christianity, he bore some of the characteristics which one would expect from a religious extremist.

Moreover, he was also an extremist in the sense that he only swore by a strictly literal method of exegesis. He refused to concede that religious scriptures embody elements of myth and mystery perhaps precisely because the essence of what such texts address cannot be reached by 
too literal a mindset. Unlike the traditional (certainly medieval) approach to hermeneutics, he did not believe that religious manuscripts contain a symbolic or mystical dimension that transcends whatever literal or moral interpretation one can ascribe to them. For Tolstoy, the four Gospels are just competing biographies of the life of a wise and rational man, biographies that were then cunningly peppered by superstitious fibs. Christianity, for him, was about ethics, not mysticism, liturgy, or theology.

Many Christians may well (not unjustifiably) object to Tolstoy's prioritization of morality, to his disrespect for ritual and for the traditional Christian canon; but for them to prove him wrong, however, a bona fide and convincing argument on why Jesus' words in the Sermon should not be taken literally - or even on why the second "commandment" should be taken literally and followed dutifully, as Tolstoy remarks it often is, but not the fourth and fifth (Tolstoy 1902, 11-13, 2001c, 40-42) - would have to be formulated first. Thus far, none of his critics have done that. ${ }^{15}$ Undeniably, Tolstoy can indeed be accused of a somewhat one-sided, even extremist reading of Christian scripture; but this could work as a call for more moderate Christians to fully spell out their alternative but truthful interpretation of the Sermon's political implications. As things stand, however, Tolstoy does not appear to be so wrong in his analysis of the response to violence that Jesus advocates. Tolstoy himself may fail to qualify as what most people would consider to be a Christian, but he does highlight passages in the New Testament that are definitely part and parcel of Christianity.

In any case, aside from the question of authenticity to Christianity, the response to violence that Tolstoy encouraged remains potentially persuasive even to an atheistic audience. Whether there is a hereafter or not, non-resistance, patience, and forgiveness may still promise a better future for humanity than the self-perpetuating path of violence, anger and retaliation. A solid case for this would require further elaboration than allowed for in this paper; but the point here is that whether or not Tolstoy is faithful to Christianity, the argument he makes for non-resistance - and the consequences of it for the "war on terror" — can also be defended on the ostensibly more scientific basis of reason. Tolstoy's conflation of reason and religion may indeed be dubious, but the rationale for non-resistance to evil is both potentially justifiable on the grounds of reason on one hand, and undeniably written into the story of Christianity on the other. 


\section{Christian Anarchism}

Nonetheless, the political ideal that Tolstoy subsequently found himself arguing for may appear to some as even more radical than his understanding of religion. That is, Tolstoy ultimately rejected the very institution of the state as unchristian and wrong (for introductions to Tolstoy's Christian anarchism, see Christoyannopoulos 2008; Hopton 2000; Marshall 1993, 362-383; Woodcock 1975, 207-219). His understanding of Jesus' commandments (including the one not to take oaths, here not critically discussed) led him to conclude that since the very existence of the state is based on the threat of violence, as embodied in the army, in prisons, in the police, and so on, the state is therefore transgressing the instruction not to resist evil, and is hence an unchristian institution. Moreover, the state's judicial system judges and punishes, again a contravention of Jesus' message. Also, a state actually defines itself against other states, thereby reinforcing distinctions between countrymen and foreigners, hence disobeying the commandment to treat all men as equals. Tolstoy's Christian anarchism is thus inseparable from his Christian pacifism, from his understanding of Christian non-violence and non-resistance (for an interesting discussion of the parallels between pacifism and anarchism, see Ostergaard 2007).

Furthermore, that the church has historically cuddled with the state does not in any way redeem the state - for Tolstoy, it only further condemns the church. Already guilty of (deliberately) misinterpreting Jesus' commandments, the church's association with the state simply provided further proof of its unfaithfulness to the essence of Christianity (Tolstoy 1902, 1934a, 1934b, 1934f, 1934g, 2001c). In Tolstoy's judgment, both state and church were fundamentally unchristian, both had systematically manipulated the masses for their own advantages, and hence both would ultimately have to be done away with by humanity (Tolstoy 1902, 2001c). So Tolstoy extracted some clearly anarchist (but non-violent) implications from his understanding of Christianity; a more elaborate analysis or a critical assessment of these Christian anarchist ideals, however, extends beyond the scope of this paper.

Either way, Tolstoy disapproved of any imposition of any law, divine or manmade, by humans upon humans - what we today miscall "justice," Tolstoy remarked, is merely brutal tit-for-tat revenge (Tolstoy 1902, 99). For him, Jesus specifically commanded human beings never to resist evil or judge one another; and this could only imply that the political system that we are still based upon today would have to be replaced 
by some (perhaps perilous) anarchist ideal. And again, whether or not Tolstoy was correct in defending such utopia, it is difficult to deny its starting point - that Jesus did clearly say that we should never use violence against one another.

In any event, Tolstoy was not alone in his radical and utopian reading of the New Testament. But it was only after he reached his political conclusions largely on his own that he discovered that other individuals and sects had believed similar things before him. Thus in The Kingdom of God Is within You, he explains that it was only after he had written What I Believe that he was made aware of the similar political views of William Lloyd Garrison, Adin Ballou, Peter Chelčický, and the Quakers (Tolstoy 2001c, 3-33). And there are others that would also sympathize with Tolstoy up to a point: some early Christians such as Origen and Tertullian, and several late medieval sects such as the Hussites, the Anabaptists, and the Mennonites also read the Gospel as implying non-resistance to evil, and for some, as questioning the legitimacy of certainly church but sometimes also state authority (Brock 1972, 1981; Marshall 1993, 74-95). And indeed after Tolstoy, people like Jacques Ellul, Vernard Eller, Dorothy Day, Ammon Hennacy, and Michael Elliott have also interpreted Christianity as abolishing the need for a state as we know it (Day 1952; Eller 1987; Elliott 1990; Ellul 1991; Missey and Thomas 1994).

So for all his apparently unique radicalism, Tolstoy's reading of Christianity has been at least partly shared by many Christians before as well as after him. Where Tolstoy is fairly unique, however, is in that he wrote the first systematic and extended explanation of how Christianity leads to non-resistance and, from there, to the redundancy of both church and state. In other words, of all these radical movements and thinkers, Tolstoy was probably the first one who most resembled a methodical Christian anarchist political theorist.

\section{TOLSTOY'S CONTEMPORARY APPEAL}

Tolstoy's reading of Christianity was fairly extreme, certainly provocative he did not shy away from verbally confronting those who did not share his particular perspective. In relaying his views, this paper does not wish to offend those who would disagree with Tolstoy. Instead, the aim is to reflect on Tolstoy's alternative way of responding to violence, and to perhaps stimulate further academic discussion, especially among political scientists, on religious political theory and more specifically on the 
theoretical political implications of Christianity. While this topic has always incited a significant amount of scholarly interest by theologians, there is little current research by political scientists that engages directly with the theoretical political dimension of the religion out of which Western civilization emerged. Tolstoy's extreme outlook could go some way toward stirring up this rather dormant facet of political science, maybe even toward inciting a dialogue between theologians and social scientists, a dialogue that could yield precious fruits for the unfolding twenty-first century.

The Christian anarchist utopia that Tolstoy elaborated from his exegesis probably seems too radical for humanity today. Still, if he were here now, he would be calling for those who define themselves as Christians to actually follow Christ and not resist evil, even in the face of terrorism, whatever the risk of being "crucified." He would further urge for a "policy" of love and care to prevent violence and hatred from arising in the first place. For violence to disappear, do not resist but love the enemy, and eventually, the enemy will have no more reasons to resist you in the first place; or at least, do not use violence, and the enemy will run out of justifications to use violence against you. For Tolstoy, only those who struggle to live out these radical instructions from the Sermon on the Mount really "have God on their side."

What is refreshing about Tolstoy's religious radicalism is that unlike so many counterparts today, it is rigorously non-violent. Although he is campaigning for more involvement of religion with politics, both the ends and the means of this involvement are peaceful. And while it is true that in the final analysis, Tolstoy may not qualify as what most people would call a "true" Christian, he does turn the spotlight on a part of the New Testament that seems to have been overlooked by Christians and non-Christians alike. Whether one is struck by terrorism or by some other form of violence, Jesus calls for one to turn the other cheek and to consider one's own prior violence in the first place. In Tolstoy's own words, what Jesus basically tells mankind is "You wish to destroy evil by evil, but that is unreasonable. That there may be no evil, do none yourselves" (Tolstoy, 1902, p. 87).

\section{NOTES}

1. That the existence of God can be rationally established is, of course, a statement that has been disputed for centuries. Tolstoy's case is both quite intricate and ultimately not overwhelmingly convincing. His position is not dissimilar to deists: he rejects any notion of a mysterious presence of God in Creation and believes that what we have received from God is the spark of reason in us all (for 
details on his reasoning, see Tolstoy 1902, 1934d, 1934h, 1987a). In any case, this issue is only secondary to the central focus of this paper (a Christian response to violence); it is mentioned here and in a little more detail later in this paper only to demonstrate how crudely rationalistic Tolstoy's view of Christianity is.

2. The King James Version is preferred here because it is the version used by English translations of Tolstoy's political and religious writings.

3. These words are usually ascribed to Mohandas K. Gandhi, but their precise reference is actually never given - and anyway, Gandhi's philosophy of non-violence was actually influenced by his reading of Tolstoy.

4. In these texts, Tolstoy mounts a bitter criticism of the "just war" tradition familiar to the majority of Christians today, which he considers a grave betrayal of Jesus, informed neither by the letter nor by the spirit of his teaching.

5. Tolstoy's exegesis here may have curious implications. It does not rule out that Jesus approved of hating one's personal enemy. Tolstoy, however, does not pursue this question further. For him, the meaning of this command became clear by referring to national enemies, and that was that. In truth, he would probably dismiss any suggestion that Jesus promoted any form of hatred, be it personal or national. In any event, this issue is secondary to the main argument of this paper.

6. Tolstoy concentrates much more on these verses of the Sermon on the Mount than on other passages in the Gospel, hence the repetition of his bias here. His view of other passages is best gleaned from his harmonized version of the Gospel (Tolstoy 1933). Other Christian anarchists and pacifists interpret the remainder of the Gospel in more detail and in ways largely compatible with Tolstoy's take on the Sermon on the Mount (for instance, Ballou 2006; Eller 1987; Elliott 1990; Ellul, 1991, 1998; Penner 2000).

7. Tolstoy here displays strong affinities with Wink (1987, 1992) and Yoder (Wogaman 2000; Yoder 1992, 1994), both prominent theologians of the Christian Left, but even more so with Ballou (2001, 2006) and Elliott (1990) in that the latter are more willing, like Tolstoy, to question and non-violently resist the Christian legitimization of the state.

8. Tolstoy seriously entertained the hope that a growing wave of conscientious objectors would pioneer the Christian regeneration of society (Tolstoy 1967a, 1987b, 2001a, 2001c).

9. Some argue that violence can be verbal as well as physical (for instance, Ellul 1970), which would imply that Tolstoy's verbal denunciations are themselves a form of violence. Tolstoy never addresses this grey area. By violence, he only really means the crude, visible, physical violence whereby a human being is physically hurt as a consequence of the actions of another human being; and - since Jesus verbally denounced religious authorities while also preaching and exemplifying non-violence and non-resistance — it is this type of violence that Tolstoy takes Jesus' commandment to be referring to.

10. Tolstoy's understanding of Jesus' call to "take up the cross" is obviously poles apart from Christian crusaders' interpretation of it as a mandate to slaughter infidels, but arguably much more in line with Jesus' teaching and example, as noted by Dave Andrews, another Christian anarchist (Andrews 2001).

11. It is undeniable that the word "martyr" carries very negative connotations in the age of suicide bombers, but this has not always been the case. The martyrs of the church, in the beginning at least, were the saints who were cruelly tortured and killed for their refusal to compromise their Christian faith. The meaning of dying while trying to kill only came with what Tolstoy sees as church theologians' deplorable perversions of Jesus' teaching: these martyrs were therefore witnesses or martyrs, yes, but to their perverted "Christian" faith. The true Christian witness, for Tolstoy, can only be a martyrdom of love, forgiveness and non-resistance — certainly not of violence and hatred.

12. Tolstoy refuses to blame the "great men" of history for the events which historians attribute to them - he wrote War and Peace precisely to reject the view that the Napoleonic Wars were Napoleon's direct responsibility (Hopton 2000, 28-32; Tolstoy 1993a). It seems to follow that he does not believe that the great evil men of history can be characterized as evil in themselves. For him, the evil is in the method more than in the human being who mistakenly adopts that method.

13. As the next section will show, he would go even further and call for the rendering obsolete of the state by the parallel enactment of a true Christian (anarchist) society. Hence he would not appeal for public expenditure to be adjusted, but for each and every Christian to spend an equivalent time and effort loving fellow human beings without relying on the state to do this for them. 
14. Tolstoy reports that this is said in Teaching of the Twelve Apostles, but he gives no reference details for these words to be traced back to their original source (Tolstoy 1937a, 250).

15. None of the critics he responds to himself (for instance, in Tolstoy 1934a, 2001c, 34-93) or those that commented on his works after his death (such as Abraham 1929; Flew 1963; FueloepMiller 1960; Greenwood 1975, 1978; Maude 1930b; Spence 1961, 1963, 1967; Stanoyevich 1926a, 1926b; Stepun 1960) really reply to him on his ground, based on a faithful interpretation of the scriptural passages which Tolstoy highlights.

\section{REFERENCES}

Abraham, J. H. 1929. "The Religious Ideas and Social Philosophy of Tolstoy." International Journal of Ethics 40:105-120.

Andrews, D. 2001. "The Crux of the Struggle." http://www.daveandrews.com.au/ publications.html.

Ballou, A. 1839. "Non-Resistance in Relation to Human Governments." http://www. nonresistance.org/literature.html.

Ballou, A. 2001. "A Catechism of Non-Resistance." In The Kingdom of God and Peace Essays, trans. A. Maude. pp. 14-19. New Delhi: Rupa.

Ballou, A. 2006. Christian Non-Resistance in All Its Important Bearings. www. nonresistance.org.

Brock, P. 1972. Pacifism in Europe to 1914. Princeton: Princeton University Press.

Brock, P. 1981. The Roots of War Resistance: Pacifism from the Early Church to Tolstoy. New York: Fellowship of Reconciliation.

Chomsky, N. 2002. Pirates and Emperors, Old and New: International Terrorism in the Real World. London: Pluto.

Christoyannopoulos, A. J. M. E. 2008. "Leo Tolstoy on the State: A Detailed Picture of Tolstoy's Denunciation of State Violence and Deception." Anarchist Studies forthcoming.

Day, D. 1952. The Long Loneliness: The Autobiography of the Legendary Catholic Social Activist. New York: Harper.

Eller, V. 1987. Christian Anarchy: Jesus' Primacy over the Powers. Eugene: Wipf and Stock.

Elliott, M. C. 1990. Freedom, Justice and Christian Counter-Culture. London: SCM.

Ellul, J. 1970. Violence: Reflections from a Christian Perspective, trans. C. Gaul Kings. London: SCM.

Ellul, J. 1991. Anarchy and Christianity, trans. G. W. Bromiley. Grand Rapids: William B. Eerdmans.

Ellul, J. 1998. "Anarchism and Christianity." In Jesus and Marx: From Gospel to Ideology, trans. J. Main Hanks, pp. 153-177. Grand Rapids: William B. Eerdmans.

Flew, A. 1963. "Tolstoi and the Meaning of Life." Ethics: An International Journal of Social, Political, and Legal Philosophy 73:110-118.

Fueloep-Miller, R. 1960. "Tolstoy the Apostolic Crusader." Russian Review 19:99-121.

Greenwood, E. B. 1975. Tolstoy: The Comprehensive View. London: Methuen.

Greenwood, E. B. 1978. "Tolstoy and Religion.” In New Essays on Tolstoy, ed. M. Jones, pp. 149-174. Cambridge: Cambridge University Press.

Hopton, T. 2000. "Tolstoy, God and Anarchism." Anarchist Studies 8:27-52.

Kennan, G. 1887. “A Visit to Count Tolstoi." The Century Magazine 34:252-265.

Kentish, J. 1987. "Introduction." In A Confession and Other Religious Writings. London: Penguin.

Leon, D. 1944. Tolstoy: His Life and Work. London: Routledge.

Marshall, P. 1993. Demanding the Impossible: A History of Anarchism. London: Fontana. 
Maude, A. 1930a. The Life of Tolstóy. London: Oxford University Press.

Maude, A. 1930b. The Life of Tolstóy: Later years. London: Oxford University Press.

Maude, A. 1933. "Editor's Note." In A Confession and the Gospel in Brief, trans. A. Maude, Vol. 11, pp. xv-xxiv. London: Oxford University Press.

Missey, J., and Thomas, J. ed. 1994. The Book of Ammon by Ammon Hennacy. Baltimore: Fortkamp.

Ostergaard, G. 2007. "Resisting the Nation State: The Pacifist and Anarchist Tradition." http://www.ppu.org.uk/e_publications/dd-trad1.html.

Penner, A. 2000. The New Testament, the Christian, and the State. Hagerstown: James Lowry/Deutsche Buchhandlung.

Spence, G. W. 1961. “Tolstoy’s Dualism.” Russian Review 20:217-231.

Spence, G. W. 1963. "Suicide and Sacrifice in Tolstoy's Ethics." Russian Review 22: $157-167$.

Spence, G. W. 1967. Tolstoy the Ascetic. Edinburgh: Oliver and Boyd.

Stanoyevich, M. S. 1926a. "Tolstoy's Theory of Social Reform. I." The American Journal of Sociology 31:577-600.

Stanoyevich, M. S. 1926b. "Tolstoy's Theory of Social Reform. II." The American Journal of Sociology 31:744-762.

Stepun, F. 1960. "The Religious Tragedy of Tolstoy." Russian Review 19:157-170.

Tolstoï, L. N. 1898. What to Do? London: Walter Scott.

Tolstoy, L. 1902. What I Believe: My Religion. London: C. W. Daniel.

Tolstoy, L. 1933. "The Gospel in Brief." In A Confession and the Gospel in Brief, trans. A. Maude, Vol. 11, pp. 113-302. London: Oxford University Press.

Tolstoy, L. 1934a. "An Appeal to the Clergy." In On Life and Essays on Religion, trans. A. Maude, Vol. 12, pp. 282-308. London: Oxford University Press.

Tolstoy, L. 1934b. "Church and State." In On Life and Essays on Religion, trans. A. Maude, Vol. 12, pp. 331-345. London: Oxford University Press.

Tolstoy, L. 1934c. "On Life." In On Life and Essays on Religion, trans. A. Maude, Vol. 12, pp. 1-167. London: Oxford University Press.

Tolstoy, L. 1934d. "Reason and Religion: A Letter to an Inquirer." In On Life and Essays on Religion, trans. A. Maude, Vol. 12, pp. 199-204. London: Oxford University Press.

Tolstoy, L. 1934e. "Religion and Morality." In On Life and Essays on Religion, trans. A. Maude, Vol. 12, pp. 168-198. London: Oxford University Press.

Tolstoy, L. 1934f. "A Reply to the Synod's Edict of Excommunication, and to Letters Received by Me Concerning It." In On Life and Essays on Religion, trans. A. Maude, Vol. 12, pp. 214-225. London: Oxford University Press.

Tolstoy, L. 1934g. "The Restoration of Hell." In On Life and Essays on Religion, trans. A. Maude, Vol. 12, pp. 309-330. London: Oxford University Press.

Tolstoy, L. 1934h. "What is Religion, and Wherein Lies its Essence?" In On Life and Essays on Religion, trans. A. Maude, Vol. 12, pp. 226-281. London: Oxford University Press.

Tolstoy, L. 1937a. "Bethink Yourselves!" In Recollections and Essays, trans. A. Maude, Vol. 21, pp. 204-271. London: Oxford University Press.

Tolstoy, L. 1937b. "Gandhi Letters." In Recollections and Essays, trans. A. Maude, Vol. 21, pp. 433-439. London: Oxford University Press.

Tolstoy, L. 1937c. "I Cannot Be Silent." In Recollections and Essays, trans. A. Maude, Vol. 21, pp. 395-412. London: Oxford University Press.

Tolstoy, L. 1937d. "A Letter to a Hindu." In Recollections and Essays, trans. A. Maude, Vol. 21, pp. 413-432. London: Oxford University Press.

Tolstoy, L. 1937e. "Thou Shalt Not Kill." In Recollections and Essays, trans. A. Maude, Vol. 21, pp. 195-203. London: Oxford University Press. 
Tolstoy, L. 1937f. "What's to Be Done?" In Recollections and Essays, trans. A. Maude, Vol. 21, pp. 384-394. London: Oxford University Press.

Tolstoy, L. 1967a. "The Beginning of the End." In Tolstoy's Writings on Civil Disobedience and Non-Violence, trans. A. Maude, pp. 9-17. New York: Bergman.

Tolstoy, L. 1967b. "Letter to Ernest Howard Crosby." In Tolstoy's Writings on Civil Disobedience and Non-Violence, trans. A. Maude, pp. 181-190. New York: Bergman.

Tolstoy, L. 1975. The Inevitable Revolution. trans. R. Sampson. London: Housmans.

Tolstoy, L. 1987a. "A Confession." In A Confession and Other Religious Writings, trans. J. Kentish, pp. 17-80. London: Penguin.

Tolstoy, L. 1987b. "The Law of Love and the Law of Violence." In A Confession and Other Religious Writings, trans. J. Kentish, pp. 151-230. London: Penguin.

Tolstoy, L. 1990a. "An Appeal to Social Reformers." In Government Is Violence: Essays on Anarchism and Pacifism, ed. D. Stephen, pp. 53-66. London: Phoenix.

Tolstoy, L. 1990b. "The End of the Age: An Essay on the Approaching Revolution." In Government Is Violence: Essays on Anarchism and Pacifism, ed. D. Stephen, pp. 21-52. London: Phoenix.

Tolstoy, L. 1993a. "Some Words about War and Peace." In War and Peace, trans. A. Maude, pp. 959-964. Ware: Wordsworth.

Tolstoy, L. 1993b. War and Peace. trans. A. Maude. Ware: Wordsworth.

Tolstoy, L. 2001a. "Christianity and Patriotism." In The Kingdom of God and Peace Essays, trans. A. Maude, pp. 422-500. New Delhi: Rupa.

Tolstoy, L. 2001b. "Introduction to a Short Biography of William Lloyd Garrison." In The Kingdom of God and Peace Essays, trans. A. Maude, pp. 530-536. New Delhi: Rupa.

Tolstoy, L. 2001c. "The Kingdom of God Is within You." In The Kingdom of God and Peace Essays, trans. A. Maude, pp. 1-421. New Delhi: Rupa.

Tolstoy, L. 2001d. "Patriotism and Government." In The Kingdom of God and Peace Essays, trans. A. Maude, pp. 501-529. New Delhi: Rupa.

Troyat, H. 1967. Tolstoy. trans. N. Amphoux. Garden City: Doubleday.

Wilson, A. N. 1988. Tolstoy: A Biography. New York: Norton.

Wink, W. 1987. Jesus' Third Way. Philadelphia: New Society.

Wink, W. 1992. Engaging the Powers: Discernment and Resistance in a World of Domination. Minneapolis: Fortress.

Wogaman, J. P. 2000. Christian Pacifist and Anarchist Perspectives. In Christian Perspectives in Politics, pp. 55-78. Louisville: Westminster John Knox.

Woodcock, G. 1975. Anarchism: A History of Libertarian Ideas and Movements. Harmondsworth: Penguin.

Yoder, J. H. 1992. The Christian Witness to the State. Scottdale: Herald.

Yoder, J. H. 1994. The Politics of Jesus: Vicit Agnus Noster. Grand Rapids: William B. Eerdmans. 